Kredo 4 (2021)
KREDO: Jurnal Ilmiah Bahasa dan Sastra
Terakreditasi Sinta 4 berdasarkan Keputusan
Direktorat Jenderal Penguatan Riset dan
Pengembangan, Kementerian Riset, Teknologi dan
Pendidikan Tinggi Republik Indonesia
Nomor: 23/E/KPT/2019.08 Agustus 2019
https://jurnal.umk.ac.id/index.php/kredo/index

\title{
MENINGKATKAN KETERAMPILAN SISWA DALAM BERDISKUSI MELALUI IMPLEMENTASI TEKNIK SINEKTIK
}

\author{
Abdul Kadir', Aziz Thaba², Abdul Karim³ \\ Abdullahkadir01@yahoo.co.id \\ ${ }^{1}$ STKIP Cokroaminoto Pinrang, Indonesia \\ ${ }^{2}$ Lembaga Swadaya Penelitian dan Pengembangan Pendidikan (LSP3) Matutu, Indonesia \\ ${ }^{3}$ Universitas Muhammadiyah Makassar, Indonesia
}

Info Artikel
Sejarah Artikel
Diterima
3 Februari 2021
Disetujui
17 Maret 2021
Dipublikasikan
7 April 2021
Keywords
sinektik techniques,
improve, skills,
discussion

Kata Kunci

teknik sinektik, keterampilan, berdiskusi

\begin{abstract}
The problem in this research is how the process of applying sinektik techniques in improving the skills discussed in class XI SMA 1 Unismuh Makassar Muhammadiyah. This study aims to improve the skills of using the technique sinektik discussion with students of class XI SMA Muhammadiyah 1 Unismuh Makassar. This study is a follow-grade (classroom action) consisting of two cycles. Each cycle held 3 meetings, the procedures of the study include action, observation and reflection. The subjects were students of class XI SMA Muhammadiyah 1 Unismuh Makassar total of 32 the number of students. The results showed that in the first cycle were completed individually from 32 students only 12 students or $37.5 \%$, which meets the minimum completeness criteria (KKM) or are in the very low category. Classically has not been met because the average value obtained for 65.16. In the second cycle of 32 the number of students there are 29 students or $96.6 \%$ have met : KKM and classically been met and that maximum value is obtained an average of 76.09 , or be in either category. Based on the above results suggested that the discussion skills can be improved through technical sinektik.
\end{abstract}




Kredo 4 (2021)
KREDO: Jurnal Ilmiah Bahasa dan Sastra
Terakreditasi Sinta 4 berdasarkan Keputusan
Direktorat Jenderal Penguatan Riset dan
Pengembangan, Kementerian Riset, Teknologi dan
Pendidikan Tinggi Republik Indonesia
Nomor: 23/E/KPT/2019.08 Agustus 2019
https://jurnal.umk.ac.id/index.php/kredo/index

\section{PENDAHULUAN}

Memasuki persaingan global dan persaingan ilmu pengetahuan, teknologi (IPTEK), dan seni yang semakin ketat antara negara-negara yang ada di dunia, bangsa Indonesia membutuhkan tekadnya untuk meningkatkan sumber daya manusia (SDM) di antaranya melalui peningkatan mutu pendidikan yang ada di Indonesia. Peningkatan mutu pendidikan merupakan batu loncatan dalam meningkatkan kualitas di berbagai bidang.

Berhubung dengan kegiatan belajar, yang terpenting adalah menciptakan kondisi atau suatu proses yang mengarahkan siswa untuk melakukan aktivitas belajar. Dalam hal ini peranan guru sangat berperan penting. Bagaimana guru melakukan usaha-usaha untuk dapat menumbuhkan dan memberikan motivasi agar siswanya melakukan aktivitas belajar dengan baik. Untuk dapat belajar dengan baik diperlukan proses dan motivasi yang baik pula. Pada dasarnya peneliti memilih objek penelitiannya pada kelas XI SMA Muhammadiyah 1 Unismuh Makassar. Karena pada kelas tersebut dinilai kurang terampil dalam berdiskusi.

Hasil observasi awal ditemukan bahwa hanya $15 \%$ siswa yang aktif dalam kegiatan berdiskusi kegiatan pembelajaran berlangsung. Temuan ini hampir seluruhnya telah dikonfirmasi oleh setiap guru bidang studi. Hal ini 369 | Jurnal Kredo

Vol. 4 No. 22021 menjelaskan bahwa kemampuan siswa memang masing sangat minim dalam hal berdiskusi. Selanjutnya, dokumen yang diberikan guru (jurnal dan laporan evaluasi belajar siswa) pada saat observasi awal cukup menjelaskan bahwa kemampuan berbicara (khususnya dalam berdiskusi) masih sangat rendah. Oleh karena itu, diperlukan upaya untuk meningkatkan kompetensi berbicara siswa khususnya dalam hal berdiskusi melalui rancangan pembelajaran yang efektif.

Salah satu teknik yang biasa dan efektif digunakan dalam melatih dan meningkatkan kemampuan berbicara siswa adalah sinektik (Rahayu 2009; Reza, Hudiyono, and Yahya 2020; Utami 2019). Oleh karena itu, upaya meningkatkan kemampuan berdiskusi siswa dalam penelitian ini diharapkan dapat terwujud dengan mengimplementasikan teknik sinektik dalam pembelajaran.

Peneliti ini bertujuan untuk mengetahui apakah dengan diterapkannya teknik sinektik dalam berdiskusi siswa kelas XI Muhammadiyah 1 Unismuh Makassar bisa meningkatkan keterampilan berbicaranya khususnya dalam kegiatan berdiskusi.

Upaya untuk meningkatkan kemampuan siswa dalam berdiskusi terlebih dahulu harus ada motivasi dari dalam diri siswa untuk berani 


Kredo 4 (2021)
KREDO: Jurnal Ilmiah Bahasa dan Sastra
Terakreditasi Sinta 4 berdasarkan Keputusan
Direktorat Jenderal Penguatan Riset dan
Pengembangan, Kementerian Riset, Teknologi dan
Pendidikan Tinggi Republik Indonesia
Nomor: 23/E/KPT/2019.08 Agustus 2019
https://jurnal.umk.ac.id/index.php/kredo/index

berpendapat dalam berdiskusi. Berdiskusi merupakan sebuah interaksi komunikasi antara dua orang atau lebih/ kelompok. Biasanya komunikasi antara mereka/kelompok tersebut berupa salah satu ilmu atau pengetahuan dasar yang akhirnya akan memberikan rasa pemahaman yang baik dan benar. Diskusi bisa berupa apa saja yang awalnya disebut topik. Agar siswa dapat mencapai tujuan dalam berdiskusi, siswa harus memiliki kemampuan dan keterampilan untuk meyampaikan informasi kepada orang lain. Hal ini bermakna bahwa pembicara harus memahami betul bagaimana cara berdiskusi yang efektif sehingga orang lain (kelompok lain) dapat menangkap informasi yang disampaikan pembicara secara efektif pula.

$$
\text { Menurut Indrizal }
$$

mendefinisikan diskusi kelompok adalah proses di mana siswa akan mendapatkan kesempatan untuk berkontribusi pegalaman mereka sendiri dalam memecahkan masalah umum. Dalam diskusi ini tetanam juga tanggung jawab dan harga diri.

Berdasarkan uraian di atas, dilakukan penelitian dengan judul "Meningkatkan Kemampuan Siswa dalam Berdiskusi Melalui Implementasi Teknik Sinektik".

\section{KAJIAN TEORI}

\section{A. Teknik Sinektik}

\section{Pengertian Teknik Sinekti}

Teknik sinektik ini adalah salah satu model pembelajaran yang dipergunakan guru dengan tujuan merangsang perkembangan kemampuan berpikir logis dengan menilai sesuatu atas pengetahuan dan pengalaman serta meningkatkan kreativitas secara lebih baik (Maulidiyah 2017). Sinektik merupakan pendekatan baru, guna mengembangkan kreatifitas, Gordon dan kawan-kawannya dalam (Mutmainnah and Aquami, 2016)

Menurut Nugraha (2017) "Model pembelajaran sinektik ini merupakan strategi yang sangat bermanfaat untuk mengembangkan pengertian baru pada diri siswa tentang suatu masalah sehingga dia sadar bagaimana bertingkah laku dalam situasi tertentu. Selain itu model pembelajaran sinektik juga bermanfaat karena dapat mengembangkan kejelasan pengertian dan internalisasi pada diri siswa tentang materi baru, dan dapat mengembangkan berpikir kreatif, baik pada diri siswa maupun guru.

\section{Kreatif dan Proses Sinektik}

Pemrosesan spesifik dalam sinektik dikembangkan dari seperangkat anggapan dasar tentang psikologi kreativitas menurut Aprinawati (2017) yaitu:

\section{MENINGKATKAN KETERAMPILAN SISWA DALAM BERDISKUSI MELALUI | 370}

IMPLEMENTASI TEKNIK SINEKTIK

Abdul Kadir ${ }^{1}$, Aziz Thaba ${ }^{2}$, Abdul Karim ${ }^{3}$ 
KREDO: Jurnal Ilmiah Bahasa dan Sastra Terakreditasi Sinta 4 berdasarkan Keputusan Direktorat Jenderal Penguatan Riset dan Pengembangan, Kementerian Riset, Teknologi dan Pendidikan Tinggi Republik Indonesia

Nomor: 23/E/KPT/2019. 08 Agustus 2019 https://jurnal.umk.ac.id/index.php/kredo/index

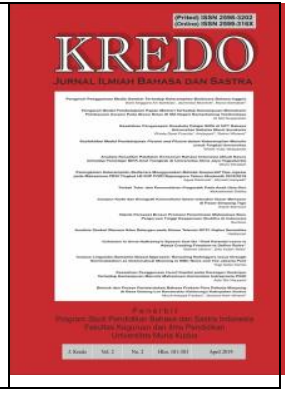

Memunculkan proses kreatif menuju kesadaran serta mengembangkannya secara nyata membantu kreativitas. Selain itu, komponen emosional lebih penting daripada komponen intelektual. Hal-hal yang bersifat irasional dapat membuka pikiran dan membimbing mental guna memungkinkan ide-ide baru. Adapun, elemen-elemen emosional dan rasional harus dipahami guna meningkatkan kemungkinan sukses dalam situasi problem solving.

\section{Tipe-tipe Analogi Sinektik}

Ada tiga tipe analogi yang dipergunakan sebagai dasar latihan sinektik yaitu (Karwati 2012):

Analogi personal, analogi ini menuntut siswa empati terhadap idea tau obyek yang dibandingkan. Siswa menjadi bagian dari elemen fisik suatu problema. Misalnya siswa diintruksikan jadilah mesin mobil, apakah yang kamu rasakan.

Analogi langsung, analogi ini adalah membedakan dua objek atau konsep secara sederhana. Fungsinya adalah menyederhanakan pengubahan kondisi-kondisi suatu kenyataan atau problema menjadi situasi yang lain untuk memperoleh suatu pandangan baru tentang idea tau problema.

Penekanan, bentuk metapora yang ketiga adalah memberi tekanan kepada pertentangan, umumnya berbentuk dua buah kata yang bertentangan misalnya, lesu-agresif, kawan-musuh.

\section{Tahap-tahap Teknik Sinektik}

Ada dua strategi yang mendasari prosedur sinektik yaitu (Karwati 2012):

a. Strategi pertama: menciptakan sesuatu yang baru

Tabel 1 Tahapan Teknik Sinektik Strategi Pertama

\begin{tabular}{|c|c|}
\hline \multicolumn{2}{|c|}{ TAHAPAN STRATEGI PERTAMA } \\
\hline $\begin{array}{l}\text { Tahap pertama: } \\
\text { mendeskripsikan }\end{array}$ & $\begin{array}{l}\text { Tahap kedua: analogi } \\
\text { langsung }\end{array}$ \\
\hline $\begin{array}{l}\text { Kondisi saat ini } \\
\text { Guru menyuruh siswa untuk } \\
\text { mendeskripsikan situasi } \\
\text { atau suatu topik yang } \\
\text { mereka lihat saat ini }\end{array}$ & $\begin{array}{l}\text { Para siswa mengemukakan } \\
\text { analogi langsung, salah satu } \\
\text { diseleksi dan selanjutnya } \\
\text { dikembangkan }\end{array}$ \\
\hline $\begin{array}{l}\text { Tahap ketiga: analogi } \\
\text { personal } \\
\text { Para siswa "manjadi" } \\
\text { analogi yang diseleksinya } \\
\text { pasa fase kedua. }\end{array}$ & $\begin{array}{l}\text { Tahap keempat: konflik } \\
\text { ditekan } \\
\text { Berdasarkan fase kedua dan } \\
\text { ketiga, para siswa } \\
\text { mengemukakan beberapa } \\
\text { konflik dan dipilih salah satu }\end{array}$ \\
\hline $\begin{array}{l}\text { Tahap kelima: analogi } \\
\text { langsung } \\
\text { Para siswa mengembangkan } \\
\text { dan menyeleksi analogi } \\
\text { langsung lainnya } \\
\text { berdasarkan konflik tadi }\end{array}$ & $\begin{array}{l}\text { Tahap keenam: meninjau } \\
\text { tugas yang sebenarnya } \\
\text { Guru menyuruh siswa } \\
\text { kembali tugas atau masalah } \\
\text { yang sebenarnya } \\
\text { menggunakan analogi dan } \\
\text { atau masuk dalam } \\
\text { pengalaman sinektik }\end{array}$ \\
\hline
\end{tabular}




Kredo 4 (2021)
KREDO: Jurnal Ilmiah Bahasa dan Sastra
Terakreditasi Sinta 4 berdasarkan Keputusan
Direktorat Jenderal Penguatan Riset dan
Pengembangan, Kementerian Riset, Teknologi dan
Pendidikan Tinggi Republik Indonesia
Nomor: 23/E/KPT/2019.08 Agustus 2019
https://jurnal.umk.ac.id/index.php/kredo/index

b. Strategi kedua: memperkenalkan keanehan.

Tabel 2 Tahapan Teknik Sinektik Strategi Kedua TAHAPAN STRATEGI KEDUA

\begin{tabular}{|c|c|}
\hline $\begin{array}{l}\text { Tahapan pertama: } \\
\text { input tentang } \\
\text { keadaan yang } \\
\text { sebenarnya } \\
\text { Guru menyajikan } \\
\text { informasi tentang } \\
\text { suatu }\end{array}$ & $\begin{array}{l}\text { Tahap kedua: analogi } \\
\text { langsung } \\
\text { Guru mengusulkan } \\
\text { analogi langsung dan } \\
\text { menyuruh siswa } \\
\text { menjabarkannya }\end{array}$ \\
\hline $\begin{array}{l}\text { Tahapan ketiga: } \\
\text { analogi personal } \\
\text { Guru menyuruh siswa } \\
\text { "menjadi" Analogi } \\
\text { langsung }\end{array}$ & $\begin{array}{l}\text { Tahap keempat: } \\
\text { membedakan analogi } \\
\text { Para siswa menjelaskan } \\
\text { dan menerangkan } \\
\text { kesamaan antara materi } \\
\text { yang baru dengan } \\
\text { analogi langsung }\end{array}$ \\
\hline $\begin{array}{l}\text { Tahap kelima: } \\
\text { menjelaskan } \\
\text { perbedaan } \\
\text { Para siswa } \\
\text { menjelaskan mana } \\
\text { analogi-analogi yang } \\
\text { tidak sesuai }\end{array}$ & $\begin{array}{l}\text { Tahap keenam: } \\
\text { penjelajah } \\
\text { Para siswa menjelajahi } \\
\text { kembali kebenaran } \\
\text { topik dengan batasan- } \\
\text { batasan mareka }\end{array}$ \\
\hline \multicolumn{2}{|c|}{$\begin{array}{l}\text { Tahapan ketujuh: membangkitkan analogi } \\
\text { Para siswa memberikan analogi sendiri secara } \\
\text { langsung Dan menjelajahi persamaan dan } \\
\text { perbedaannya. }\end{array}$} \\
\hline
\end{tabular}

Pada strategi kedua ini para siswa mencoba menghubungkan dua ide dan mengindentifikasi hubungan-hubungan dengan analogi mereka yang telah berjalan.

\section{Kelebihan dan Kelemahan Model Pembelajaran Sinektik}

Kelebihan dari strategi ini, yaitu bermanfaat untuk mengembangkan pengertian baru pada diri siswa tentang suatu masalah sehingga dia sadar bagaimana bertingkah laku dalam situasi tertentu.

Selain itu, strategi ini bermanfaat karena dapat mengembangkan kejelasan pengertian dan internalisasi pada diri siswa tentang materi baru. Kemudian, strategi ini dapat mengembangkan berpikir kreatif, baik pada diri siswa maupun guru. Strategi ini dilaksanakan dalam suasana kebebasan intelektual dan kesamaan martabat antara siswa. Dan, strategi ini membantu siswa menemukan cara berpikir baru dalam memecahkan suatu masalah.

Kelemahannya, antara lain sulit dilakukan oleh guru dan siswa yang sudah terbiasa menggunakan cara lama yang menekankan pada penyampaian informasi. Selain itu, metode ini menitikberatkan seseorang berpikir reflektif dan imajinatif dalam situasi tertentu, maka kemungkinan besar siswa kurang menguasai fakta-fakta dan prosedur pelaksanaan atau keterampilan.

\section{B. KETERAMPILAN BERDISKUSI}

\section{Pengertian Keterampilan}

Pada hakikatnya keterampilan adalah suatu ilmu yang diberikan kepada manusia, kemampuan manusia dalam mengembangkan keterampilan yang dipunyai memang tidak mudah, perlu 


Kredo 4 (2021)
KREDO: Jurnal Ilmiah Bahasa dan Sastra
Terakreditasi Sinta 4 berdasarkan Keputusan
Direktorat Jenderal Penguatan Riset dan
Pengembangan, Kementerian Riset, Teknologi dan
Pendidikan Tinggi Republik Indonesia
Nomor: 23/E/KPT/2019.08 Agustus 2019
https://jurnal.umk.ac.id/index.php/kredo/index

mempelajari, perlu menggali agar lebih terampil (Zubaidah, 2016).

\section{Pengertian Berdiskusi}

Pengertian berdiskusi adalah salah satu bentuk kegiatan wicara dengan pertukaran pikiran, gagasan, yang terdiri dari dua orang atau lebih secara lisan untuk mencari kesepakatan atau kesepahaman gagasan atau pendapat (Cahyaningrum, dkk, 2018).

\section{Unsur-unsur Berdiskusi}

Agar dikusi bisa berjalan dengan lancar maka setiap unsur diskusi harus menjalankan tugas dan perannya tersebut dengan baik. Tugas unsur-unsur diskusi menurut Indrizal (2014) adalah sebagai berikut:

Tugas moderator atau pemimpin diskusi, yaitu menyiapkan pokok masalah yang akan dibicarakan, membuka diskusi dan menjelaskan topik diskusi, memperkenalkan komponen diskusi terutama pembicara jika unsur pembicara/ penyaji, mengatur proses penyampaian gagasan atau tanya jawab, kelima menyimpulkan diskusi dan membacakan simpulan diskusi, dan menutup diskusi.

Tugas pembicara, yaitu menyiapkan materi diskusi sesuai topik yang akan dibahas, dan menyajikan pembahasan materi atau menyampaikan gagasan-gagasan serta pandangan yang berkaitan dengan topik diskusi menjawab pertanyaan secara objektif dan argumentatif.

Tugas dan peranan notulis adalah mencatat topik permasalahan, waktu dan tempat diskusi berlangsung, mencatat segala proses yang langsung dalam diskusi, menuliskan kesimpulan atau hasil diskusi, dan membuat laporan hasil diskusi.

Peranan atau tugas peserta diskusi adalah mengikuti tata tertib dan aturan dalam diskusi, mempelajari topik/permasalahan diskusi, mengajukan sanggahan berupa pertanyaan, pendapat, maupun usulan, bersikap santun dan tidak emosional, turut serta menjaga kelancaran dan kenyamanan diskusi, dan sebagai pengamat (tugas dan peran pengamat penyeimbang dalam diskusi).

\section{Macam-macam Diskusi}

Adapun macam-macam diskusi menurut Suhartinah (2018) adalah sebagai berikut:

Seminar, adalah diskusi yang digunakan untuk mencari kesepakatan atau kesamaan langkah atau pandangan dalam menghadapi suatu persoalan yang sifatnya formal.

Simposium, adalah diskusi yang diselenggarakan untuk membahas mengenai prasarana-prasarana tentang suatu pokok persoalan atau masalah. Simposium adalah diskusi yang bertujuan untuk mengetahui aspek suatu

\section{3 | Jurnal Kredo}

Vol. 4 No. 22021 


Kredo 4 (2021)
KREDO: Jurnal Ilmiah Bahasa dan Sastra
Terakreditasi Sinta 4 berdasarkan Keputusan
Direktorat Jenderal Penguatan Riset dan
Pengembangan, Kementerian Riset, Teknologi dan
Pendidikan Tinggi Republik Indonesia
Nomor: 23/E/KPT/2019.08 Agustus 2019
https://jurnal.umk.ac.id/index.php/kredo/index

masalah dalam waktu yang relatif singkat.

Konferensi, adalah pertemuan untuk berunding atau bertukar pendapat terhadap suatu masalah yang sedang dihadapi bersama.

Brainstroming, adalah diskusi yang digunakan utuk memecahkan suatu masalah. Brainstroming lebih cenderung kepada pengungkapaan pendapat oleh para peserta diskusi.

Diskusi panel, adalah diskusi yang digunakan untuk memperluas wawasan terhadap suatu masalah yang sedang hangat dengan melibatkaan beberapa ahli disiplin.

Kolokium, adalah diskusi yang menghadirkan para ahli di bidangnya sebagai narasumber untuk meluruskan suatu permasalahan yang menyimpang

Workshop/Lokakarya, adalah pertemuan yang dihadiri oleh sekelompok orang dengan latar belakang pekerjaan yang sama.

Debat, merupakan kegiatan adu argumeentasi antara dua pihak atau lebih, baik secara perorangan maupun kelompok, dalam mendiskusikan dan memutuskan masalah dan perbedaan.

\section{PEMBELAJARAN BAHASA INDONESIA}

\section{Definisi Pembelajaran Bahasa Indonesia}

Haling (2007:14) dalam (Usman, 2019) menyatakan bahwa pembelajaran adalah suatu proses yang dilaksanakan secara sistematik pada setiap komponen yang saling berpengaruh.

Adapun fungsi utama bahasa adalah sebagai alat komunikasi, sedangkan hakikat belajaar bahasa adalah belajar berkomunikasi (Wicaksono and Roza 2015). Oleh karena itu, pembelajaraan bahasa Indonesia diarahkan untuk meningkatkan keterampilan siswa dalam berkomunikasi dengan menggunakan bahasa Indonesia yang benar, baik secara lisan maupun secara tertulis.

Tujuan pembelajaran bahasa menurut Widodo (2005) adalah keterampilan berkomukasi dalam berbagai konteks komunikasi. Kemampuan yang dikembangkan adalah daya tangkap makna, peran, daya tafsir, menilai dan mengekspresikan diri dengan berbahasa.

\section{Unsur-unsur}

\section{Bahasa Indonesia}

Unsur-unsur pembelajarn menurut Haling (2007) yaitu:

a. Bahan Ajar

Pembelajar memiliki peranan penting dalam pemilihan dan penetapan bahan pelajaran. Pertimbanganpertimbangan yang perlu diperhatikan, yaitu sesuai tidaknya isi pelajaran 


Kredo 4 (2021)
KREDO: Jurnal Ilmiah Bahasa dan Sastra
Terakreditasi Sinta 4 berdasarkan Keputusan
Direktorat Jenderal Penguatan Riset dan
Pengembangan, Kementerian Riset, Teknologi dan
Pendidikan Tinggi Republik Indonesia
Nomor: 23/E/KPT/2019.08 Agustus 2019
https://jurnal.umk.ac.id/index.php/kredo/index

dengan sasaran belajar, tingkat kesukaran bahan ajar harus disesuaikan dengan pembelajaran, kesesuaian isi bahan pelajaran dengan strategi pembelajaran, kesesuaian evaluasi hasil belajar dengan bahan pembelajaran, dan suasana belajar

Beberapa pertimbangan penting bagi pembelajaran dalam rangka menciptakan suasana belajar, yaitu kenyamanan gedung sekolah untuk belajar, keakraban orang tua pembelajar dengan staf-staf pembelajar, dan pergaulan pembelajar di sekolah.

b. Media dan Sumber Belajar

Pembelajar sebagai perancang dan pengguna media dan sumber belajar dalam kegiatan pembelajaran harus dipertimbangkan beberapa hal, yaitu bermanfaat tidaknya media dan sumber belajar untuk mencapai sasaran belajar, dan sesuai tidaknya media dan sumber belajar dengan bahan pelajaran yang akan diajarkan.

c. Guru Sebagai Subjek Pembelajaran

Guru memiliki peranan penting dalam kegiatan pembelajaran, yaitu membuat desain pembelajaran secara tertulis, lengkap, dan menyeluruh, meningkatkan diri untuk menjadi seorang guru yang berkepribadian utuh, bertindak sebagai guru yang mendidik, dan dalam berhadapan dengan pelajar, guru berperan sebagai fasilisator belajar, pembimbing belajar, dan pemberi balikan belajar.

375 | Jurnal Kredo

Vol. 4 No. 22021

\section{METODE PENELITIAN}

Jenis penelitian yang digunakan adalah Penelitian Tindakan Kelas (PTK) yang dalam bahasa Inggris dikenal sebagai Classroom Action Research (CAR) yaitu sebuah penelitian yang dilakukan di kelas. Penelitian tindakan kelas ini dilaksanakan dalam pembelajaran bahasa Indonesia dalam dua siklus tindakan. Penelitian ini dilaksanakan di SMA Muhammadiyah 1 Unismuh Makassar. Subjek dari penelitian ini adalah siswa kelas XI SMA Muhammadiyah 1 Unismuh Makassar tahun ajaran 2018/2019 dengan jumlah siswa 32 orang yang terdiri atas siswa laki-laki 19 orang dan siswa perempuan 13 orang. Instrumen yang digunakan dalam penelitian ini yaitu hasil observasi dan tes hasil belajar. Data yang terkumpul selanjutnya dianalisis dengan menggunakan analisis deskriptif. Analisis data deskriptif digunakan untuk menghitung nilai rata-rata dan persentase hasil belajar. 


Kredo 4 (2021)
KREDO: Jurnal Ilmiah Bahasa dan Sastra
Terakreditasi Sinta 4 berdasarkan Keputusan
Direktorat Jenderal Penguatan Riset dan
$\begin{gathered}\text { Pengembangan, Kementerian Riset, Teknologi dan } \\ \text { Pendidikan Tinggi Republik Indonesia } \\ \text { Nomor: 23/E/KPT/2019. 08 Agustus 2019 } \\ \text { https://jurnal.umk.ac.id/index.php/kredo/index }\end{gathered}$

\section{HASIL DAN PEMBAHASAN}

\section{A. HASIL}

\section{Siklus I}

Hasil observasi proses pelaksanaan pembelajaran menggunakan teknik sinektik pada siswa kelas XI SMA Muhammadiyah 1 Unismuh Makassar pada siklus I diuraikan sebagai berikut:

Tabel 3 Lembar Observasi Kegiatan Belajar Siswa Siklus I

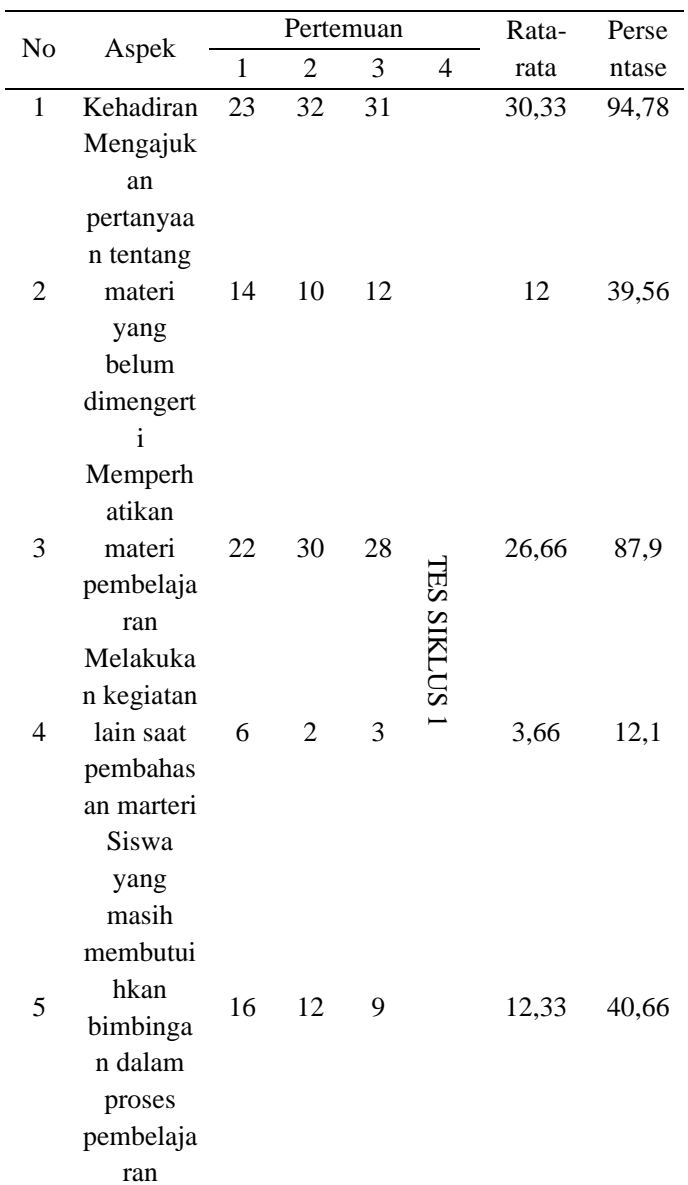

$$
\begin{aligned}
& \text { Siswa } \\
& \text { yang aktif } \\
& 6 \text { berdisuku } 18 \quad 20 \quad 18 \quad 18,66 \quad 61,54 \\
& \text { si dalam } \\
& \text { kelas }
\end{aligned}
$$

Berdasarkan tabel di atas diperoleh data observasi kegiatan belajar siswa sebagai berikut:

Rata-rata persentase kehadiran siswa yang mengikuti kegiatan pembelajaran pada siklus I sebesar $94,78 \%$. Rata-rata persentase siswa yang mengajukan pertanyaan tentang materi pelajaran yang belum dimengerti $39,56 \%$. Rata-rata persentase siswa yang memperhatikan pembahasan materi pelajaran sebesar $87,9 \%$. Rata-rata persentase siswa yang melaksanakan kegiatan lain pada saat pembahasan materi pelajaran $12,1 \%$. Rata-rata persentase siswa yang masih perlu bimbingan dalam proses pembelajaran $40,66 \%$. Rata-rata persentase siswa yang mampu aktif berdiskusi di dalam kelas $61,54 \%$

\section{Siklus II}

Pada siklus II proses pembelajaran bahasa Indonesia menggunakan teknik sinektik dilaksanakan selama 3 kali pertemuan. Setiap pertemuan berlangsung selama 2 x 40 menit. Kegiatan observasi dilakukan dengan menggunakan format observasi siswa yang telah ditetapkan sebelumnya. Hasil proses pelaksanaan pembelajaran pada siklus II diuraikan sebagai berikut: 


Kredo 4 (2021)
KREDO: Jurnal Ilmiah Bahasa dan Sastra
Terakreditasi Sinta 4 berdasarkan Keputusan
Direktorat Jenderal Penguatan Riset dan
Pengembangan, Kementerian Riset, Teknologi dan
Pendidikan Tinggi Republik Indonesia
Nomor: 23/E/KPT/2019.08 Agustus 2019
https://jurnal.umk.ac.id/index.php/kredo/index

Tabel 4 Lembar Observasi Kegiatan Belajar Siswa Siklus II

\begin{tabular}{|c|c|c|c|c|c|c|c|}
\hline \multirow{2}{*}{$\begin{array}{l}\mathrm{N} \\
\mathrm{O}\end{array}$} & \multirow{2}{*}{ Aspek } & \multicolumn{4}{|c|}{ Petemuan } & \multirow{2}{*}{$\begin{array}{c}\text { Rata- } \\
\text { rata }\end{array}$} & \multirow{2}{*}{$\begin{array}{l}\text { Perse } \\
\text { ntase }\end{array}$} \\
\hline & & 1 & 2 & 3 & 4 & & \\
\hline 1 & $\begin{array}{c}\text { Kehadiara } \\
n\end{array}$ & 32 & 32 & 32 & & 32 & $100 \%$ \\
\hline & $\begin{array}{l}\text { Mengajuk } \\
\text { an } \\
\text { pertanyaa }\end{array}$ & & & & & & \\
\hline 2 & $\begin{array}{c}\mathrm{n} \text { tentang } \\
\text { materi } \\
\text { yang } \\
\text { belum }\end{array}$ & 16 & 19 & 14 & & $16,33 \%$ & $\begin{array}{c}51,04 \\
\%\end{array}$ \\
\hline & dimengert & & & & & & \\
\hline & $\mathrm{i}$ & & & & & & \\
\hline & $\begin{array}{c}\text { Memperh } \\
\text { atikan }\end{array}$ & & & & & & \\
\hline 3 & $\begin{array}{c}\text { pembahas } \\
\text { an materi } \\
\text { pelajaran }\end{array}$ & 26 & 30 & 30 & & $26,66 \%$ & $89,6 \%$ \\
\hline & $\begin{array}{c}\text { Melaksan } \\
\text { akan }\end{array}$ & & & & 幽 & & \\
\hline 4 & $\begin{array}{c}\text { kegiatan } \\
\text { lain saat } \\
\text { pembahas } \\
\text { an materi }\end{array}$ & 6 & 2 & 3 & 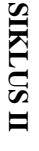 & $3,33 \%$ & $10,4 \%$ \\
\hline & $\begin{array}{c}\text { Siswa } \\
\text { yang } \\
\text { masih } \\
\text { perlu }\end{array}$ & & & & & & \\
\hline 5 & $\begin{array}{c}\text { bimbinga } \\
\mathrm{n} \text { dalam } \\
\text { proses }\end{array}$ & 8 & 8 & 3 & & $6,33 \%$ & $\begin{array}{c}19,79 \\
\%\end{array}$ \\
\hline & $\begin{array}{l}\text { pembelaja } \\
\text { ran }\end{array}$ & & & & & & \\
\hline & $\begin{array}{c}\text { Siswa } \\
\text { yang } \\
\text { mampu }\end{array}$ & & & & & & \\
\hline 6 & $\begin{array}{c}\text { aktif } \\
\text { berdiskusi } \\
\text { didalam } \\
\text { kelas }\end{array}$ & 22 & 22 & 26 & & $23,33 \%$ & $\begin{array}{c}72,91 \\
\%\end{array}$ \\
\hline
\end{tabular}

Berdasarkan tabel di atas diperoleh data observasi kegiatan belajar siswa sebagai berikut:

Rata-rata persentase kehadiran siswa yang mengikuti kegiatan pembelajaran pada siklus II sebesar
$100 \%$, rata-rata pesentase siswa yang mengajukan pertanyaan tentang materi pelajaran yang belum dimengerti $51,04 \%$, rata-rata pesentase siswa yang memperhatikan pembahasan materi pelajaran sebesar $89,6 \%$, rata-rata pesentase siswa yang melaksanakan kegiatan lain pada saat pembahasan materi pembelajara $10,4 \%$, rata-rata persentase siswa yang masih perlu bimbingan dalam proses pembelajaran $19,79 \%$, dan rata-rata persentase siswa yang mampu aktif berdiskusi di dalam kelas $72,91 \%$.

\section{B. Hasil Evaluasi \\ 1. Siklus I}

Berdasarkan hasil evaluasi yaitu berupa tes hasil belajar siswa diperoleh tabel statistik deskriptif sebagai berikut:

a. Keberanian Siswa untuk Berbicara

Tabel 5 Perolehan Skor Aspek Keaktifan Siswa dalam Berdiskusi

\begin{tabular}{ccccc}
\hline No & $\begin{array}{c}\text { Rentangan } \\
\text { Skor }\end{array}$ & $\begin{array}{c}\text { Frekuen } \\
\text { si }\end{array}$ & $\begin{array}{c}\text { Persentase } \\
(\%)\end{array}$ & Kategori \\
\hline 1 & 20 & 8 & $25 \%$ & $\begin{array}{c}\text { Sangat } \\
\text { Tinggi }\end{array}$ \\
2 & 15 & 12 & $37,5 \%$ & $\begin{array}{c}\text { Tinggi } \\
3\end{array}$ \\
2 & 10 & 9 & $28,12 \%$ & Sedang \\
4 & 5 & 3 & $9,38 \%$ & Rendah \\
& Jumlah & $\mathbf{3 2}$ & $\mathbf{1 0 0 \%}$ & \\
\hline
\end{tabular}

Berdasarkan tabel 5 sejumlah 8 orang (25\%) siswa yang memperoleh nilai pada kategori sangat tinggi. Sejumlah 12 orang $(37,5 \%)$ siswa mendapatkan nilai pada kategori tinggi. Ada 9 orang $(28,12 \%)$ siswa mendapat nilai kategori sedang. Pada kategori rendah terdapat 3 orang $(9,38 \%)$ siswa. 


Kredo 4 (2021)
KREDO: Jurnal Ilmiah Bahasa dan Sastra
Terakreditasi Sinta 4 berdasarkan Keputusan
Direktorat Jenderal Penguatan Riset dan
Pengembangan, Kementerian Riset, Teknologi dan
Pendidikan Tinggi Republik Indonesia
Nomor: 23/E/KPT/2019.08 Agustus 2019
https://jurnal.umk.ac.id/index.php/kredo/index

b. Artikulasi dan Vokal yang Tepat

Tabel 6 Perolehan Skor Aspek Artikulasi dan Vokal yang Tepat

\begin{tabular}{ccccc}
\hline No & $\begin{array}{c}\text { Rentangan } \\
\text { Skor }\end{array}$ & $\begin{array}{c}\text { Frekuen } \\
\text { si }\end{array}$ & $\begin{array}{c}\text { Persentase } \\
(\mathbf{\%})\end{array}$ & Kategori \\
\hline 1 & 20 & 8 & $25 \%$ & $\begin{array}{c}\text { Sangat } \\
\text { Tinggi }\end{array}$ \\
2 & 15 & 12 & $37,5 \%$ & Tinggi \\
3 & 10 & 9 & $28,12 \%$ & Sedang \\
4 & 5 & 3 & $9,38 \%$ & Rendah \\
& Jumlah & $\mathbf{3 2}$ & $\mathbf{1 0 0 \%}$ & \\
\hline
\end{tabular}

Berdasarkan data pada tabel di atas sebanyak 6 siswa $(18,75 \%)$ memperoleh nilai pada kategori sangat tinggi. Sebanyak 16 siswa (50\%) mendapatkan nilai pada kategori tinggi. Sebanyak 8 orang $(25 \%)$ mendapat nilai pada kategori sedang. Selanjutnya, sebanayak 2 siswa $(6,25 \%)$ mendapat nilai kategori rendah.

\section{c. Sikap dalam Berdiskusi}

Tabel 7 Perolehan Skor Aspek Sikap dalam Berdiskusi

\begin{tabular}{|c|c|c|c|c|}
\hline No & $\begin{array}{c}\text { Rentangan } \\
\text { Skor }\end{array}$ & Frekuensi & $\begin{array}{c}\text { Persentase } \\
(\%)\end{array}$ & Kategori \\
\hline 1 & 20 & 4 & $12,5 \%$ & $\begin{array}{l}\text { Sangat } \\
\text { Tinggi }\end{array}$ \\
\hline 2 & 15 & 16 & $50 \%$ & Tinggi \\
\hline 3 & 10 & 8 & $25 \%$ & Sedang \\
\hline 4 & 5 & 4 & $12,5 \%$ & Rendah \\
\hline & Jumlah & 32 & $100 \%$ & \\
\hline
\end{tabular}

sebanyak 4 siswa $(12,5 \%)$ mendapat nilai pada kategori sangat tinggi. Sebanyak 16 siswa (50\%) mendapatkan nilai pada kategori tinggi. Sebanyak 8 siswa $(25 \%)$ mendapatkan nilai pada kategori sedang. Selanjutnya, ada 4 siswa $(12,5 \%)$ mendapat nilai pada kategori rendah. d. Struktur Kalimat dan Diksi

Tabel 8 Perolehan Skor Aspek Struktur Kalimat dan Diksi

\begin{tabular}{ccccc}
\hline No & $\begin{array}{c}\text { Rentangan } \\
\text { Skor }\end{array}$ & Frekuensi & $\begin{array}{c}\text { Persentase } \\
(\mathbf{\%})\end{array}$ & Kategori \\
\hline 1 & 20 & 2 & $6,25 \%$ & Sangat \\
2 & 15 & 13 & $40,63 \%$ & Tinggi \\
3 & 10 & 8 & $25 \%$ & Singgi \\
4 & 5 & 9 & $28,12 \%$ & Redang \\
& Jumlah & $\mathbf{3 2}$ & $\mathbf{1 0 0 \%}$ & \\
\hline
\end{tabular}

Berdasarkan pada tabel 8 sebanyak

2 siswa $(6,25 \%)$ mendapat nilai pada kategori sangat tinggi. Sebanyak 13 siswa $(40,63 \%)$ mendapat nilai pada kategori tinggi. Sebanyak 8 siswa (25\%) mendapat nilai pada kategori sedang. Selanjutnya, ada 9 siswa $(28,12 \%)$ mendapat nilai pada kategori rendah.

e. Penggunaan Konjungsi dan Kalimat Peralihan

Tabel 9 Perolehan Skor Aspek Penggunaan Konjungsi dan Kalimat

\begin{tabular}{ccccc}
\hline No & $\begin{array}{c}\text { Rentangan } \\
\text { Skor }\end{array}$ & $\begin{array}{c}\text { Frekuen } \\
\text { si }\end{array}$ & $\begin{array}{c}\text { Persentase } \\
(\mathbf{\%})\end{array}$ & Kategori \\
\hline 1 & 20 & 4 & $12,5 \%$ & Sangat \\
& & & Tinggi \\
2 & 15 & 15 & $46,70 \%$ & Tinggi \\
3 & 10 & 12 & $37,5 \%$ & Sedang \\
4 & 5 & 1 & $3,3 \%$ & Rendah \\
& Jumlah & $\mathbf{3 2}$ & $\mathbf{1 0 0 \%}$ & \\
\hline
\end{tabular}

Berdasarkan data pada tabel 9 sebanyak 4 siswa $(12,5 \%)$ medapatkan nilai pada kategori sangat tinggi. Sebanyak 15 siswa $(46,70 \%)$ mendapatkan nilai pada kategori tinggi. Sebanyak 12 siswa $(37,5 \%)$ mendapat nilai pada kategori sedang. Selanjutnya, ada 1 siswa $(3,3 \%)$ mendapat nilai pada kategori

rendah. 


Kredo 4 (2021)
KREDO: Jurnal Ilmiah Bahasa dan Sastra
Terakreditasi Sinta 4 berdasarkan Keputusan
Direktorat Jenderal Penguatan Riset dan
Pengembangan, Kementerian Riset, Teknologi dan
Pendidikan Tinggi Republik Indonesia
Nomor: 23/E/KPT/2019.08 Agustus 2019
https://jurnal.umk.ac.id/index.php/kredo/index

Secara umum, kemampuan berbicara siswa pada siklus I dari kelima aspek penilaian disajikan dalam tabel berikut:

Tabel 10 Rekapitulasi Pencapaian Nilai Siklus I

\begin{tabular}{ccccc}
\hline No & $\begin{array}{c}\text { Rentang } \\
\text { Skor }\end{array}$ & $\begin{array}{c}\text { Frekuen } \\
\text { si }\end{array}$ & $\begin{array}{c}\text { Persentase } \\
(\mathbf{\%})\end{array}$ & Kategori \\
\hline 1 & $85-100$ & 2 & $6,25 \%$ & $\begin{array}{c}\text { Sangat } \\
\text { Tinggi }\end{array}$ \\
& & & & Tinggi \\
2 & $65-84$ & 18 & $56,25 \%$ & Sedang \\
3 & $55-65$ & 6 & $18,75 \%$ & Rendah \\
4 & $35-54$ & 6 & $18,75 \%$ & Sangat \\
5 & $0-34$ & - & 0 & Rendah \\
& & & &
\end{tabular}

Berdasarkan data pada tabel 10 sebanyak 2 siswa $(6,25 \%)$ memperoleh nilai pada kategori sangat tinggi. Ada 18 siswa $(56,25 \%)$ memperoleh nilai pada kategori tinggi. Sebanyak 6 siswa $(18,75 \%)$ mendapat nilai pada kategori sedang, dan ada 6 siswa $(18,75 \%)$ mendapat nilai pada kategori rendah.

\section{Siklus II}

Tahap evalusai digunakan untuk mengukur kemampuan berbicara siswa melalui teknik sinektik. Ada lima aspek penting dalam penelitian menggunakan teknik sinektik yaitu keberanian untuk berbicara, artikulasi, vokal, sikap, struktur kalimat dan diksi, serta penggunaan konjungsi dan kalimat peralihan.

Berdasarkan hasil evaluasi yaitu berupa tes hasil belajar siswa diperoleh tabel statistic deskriptif sebagai berikut:

a. Keberanian Siswa Untuk Berbicara dalam Berdiskusi

377 | Jurnal Kredo

Vol. 4 No. 22021
Tabel 11 Perolehan Skor Aspek Keberanian Berbicara dalam Berdiskusi

\begin{tabular}{|c|c|c|c|c|}
\hline No & $\begin{array}{l}\text { Rentang } \\
\text { an Skor }\end{array}$ & Frekuensi & $\begin{array}{c}\text { Persentas } \\
\text { e }(\%)\end{array}$ & Kategori \\
\hline 1 & 20 & 25 & $78,125 \%$ & $\begin{array}{l}\text { Sangat } \\
\text { Tinggi }\end{array}$ \\
\hline 2 & 15 & 5 & $15,625 \%$ & Tinggi \\
\hline 3 & 10 & 2 & $6,25 \%$ & Sedang \\
\hline 4 & 5 & - & - & Rendah \\
\hline & Jumlah & 32 & $100 \%$ & \\
\hline
\end{tabular}

sebanyak 25 siswa $(78,125 \%)$ mendapatkan nilai pada kategori sangat tinggi, sebanyak 5 siswa $(15,625 \%)$ mendapat nilai pada kategori tinggi. Sebanyak 2 siswa $(6,25 \%)$ mendapat nilai pada kategori sedang, dan tidak ada siswa yang mendapat nilai pada kategori rendah.

b. Artikulasi dan Vokal yang Tepat

Tabel 11 Perolehan Skor Aspek Artikulasi dan Vokal yang Tepat

\begin{tabular}{ccccc}
\hline $\begin{array}{c}\text { N } \\
\text { o }\end{array}$ & $\begin{array}{c}\text { Rentanga } \\
\text { n Skor }\end{array}$ & Frekuensi & $\begin{array}{c}\text { Persentas } \\
\text { e (\%) }\end{array}$ & Kategori \\
\hline 1 & 20 & 10 & $31,25 \%$ & Sangat \\
2 & 15 & 17 & $53,125 \%$ & Tinggi \\
3 & 10 & 5 & $15,625 \%$ & Sedang \\
4 & 5 & - & - & Rendah \\
& Jumlah & $\mathbf{3 2}$ & $\mathbf{1 0 0 \%}$ & \\
\hline
\end{tabular}

Berdasarkan data pada tabel 11 sebanyak $10 \quad$ siswa $(31,25 \%)$ mendapatkan nilai pada kategori sangat tinggi. Sebanyak 17 siswa $(53,125 \%)$ mendapat nilai pada kategori tinggi. Sebanyak 5 siswa $(15,625 \%)$ mendapat nilai pada kategori sedang, dan tidak ada siswa yang mendapat nilai pada kategori rendah. 


Kredo 4 (2021)
KREDO: Jurnal Ilmiah Bahasa dan Sastra
Terakreditasi Sinta 4 berdasarkan Keputusan
Direktorat Jenderal Penguatan Riset dan
Pengembangan, Kementerian Riset, Teknologi dan
Pendidikan Tinggi Republik Indonesia
Nomor: 23/E/KPT/2019.08 Agustus 2019
https://jurnal.umk.ac.id/index.php/kredo/index

c. Sikap dalam Berdiskusi

Tabel 12 Perolehan Skor Aspek Sikap dalam Berdiskusi

\begin{tabular}{ccccc}
\hline No & $\begin{array}{c}\text { Rentang } \\
\text { an Skor }\end{array}$ & Frekuensi & $\begin{array}{c}\text { Persentas } \\
\text { e (\%) }\end{array}$ & Kategori \\
\hline 1 & 20 & 8 & $25 \%$ & $\begin{array}{c}\text { Sangat } \\
\text { Tinggi }\end{array}$ \\
2 & 15 & 14 & $43,75 \%$ & Tinggi \\
3 & 10 & 10 & $31,25 \%$ & Sedang \\
4 & 5 & - & - & Rendah \\
& Jumlah & $\mathbf{3 2}$ & $\mathbf{1 0 0 \%}$ & \\
\hline
\end{tabular}

Berdasarkan data pada tabel 12 sebanyak 8 siswa (25\%) mendapat nilai pada kategori sangat tinggi. Sebanyak 14 siswa $(43,75 \%)$ mendapat nilai pada kategori tinggi, sebanyak 10 siswa $(31,25 \%)$ mendapat nilai pada kategori sedang dan tidak ada siswa yang mendapat nilai pada kategori rendah.

\section{d. Strutur Kalimat dan Diksi}

Tabel 13 Perolehan Skor Aspek Struktur Kalimat dan Diksi

\begin{tabular}{ccccc}
\hline No & $\begin{array}{c}\text { Rentanga } \\
\text { n Skor }\end{array}$ & Frekuensi & $\begin{array}{c}\text { Persentase } \\
(\mathbf{\%})\end{array}$ & Kategori \\
\hline 1 & 20 & 2 & $6,25 \%$ & $\begin{array}{c}\text { Sangat } \\
\text { Tinggi }\end{array}$ \\
2 & 15 & 18 & $56,25 \%$ & Tinggi \\
3 & 10 & 10 & $31,25 \% \%$ & Sedang \\
4 & 5 & 2 & $6,25 \%$ & Rendah \\
& Jumlah & $\mathbf{3 2}$ & $\mathbf{1 0 0 \%}$ & \\
\hline
\end{tabular}

Berdasarkan data pada tabel 13 sebanyak 2 siswa $(6,25 \%)$ mendapat nilai pada kategori sanat tinggi. Sebanyak $18 \quad(56,25 \%)$ mendapatkan nilai pada kategori tinggi. Sebanyak 10 siswa $(31,25 \%)$ mendapat nilai pada kategori sedang, dan 2 siswa $(6,25 \%)$ mendapat nilai pada kategori rendah. e. Penggunaan Konjungsi dan Kalimat Peralihan

Tabel 14 Perolehan Skor Aspek Penggunaan Konjungsi dan Kalimat

\begin{tabular}{ccccc}
\hline No & $\begin{array}{c}\text { Rentang } \\
\text { an Skor }\end{array}$ & Frekuensi & $\begin{array}{c}\text { Persentase } \\
(\mathbf{\%})\end{array}$ & Kategori \\
\hline 1 & 20 & 3 & $9,375 \%$ & $\begin{array}{c}\text { Sangat } \\
\text { Tinggi }\end{array}$ \\
2 & 15 & 18 & $56,25 \%$ & Tinggi \\
3 & 10 & 10 & $31,25 \%$ & Sedang \\
4 & 5 & 1 & $3,125 \%$ & Rendah \\
& Jumlah & $\mathbf{3 2}$ & $\mathbf{1 0 0 \%}$ & \\
\hline
\end{tabular}

Berdasarkan data pada tabel 14 sebanyak 3 siswa $(9,375 \%)$ mendapat nilai pada kategori sangat tinggi, sebanyak 18 siswa $(56,25 \%)$ mendapat nilai pada kategori tinggi, sebanyak 10 siswa $(31,25 \%)$ mendapat nilai pada kategori sedang, dan 1 siswa $(3,125 \%)$ mendapat nilai pada kategori rendah. Secara umum, kemampuan berbicara siswa pada siklus II dan kelima aspek penilaian disajikan dalam tabel berikut:

Tabel 15 Rekapitulasi Pencapaian Nilai Siklus II

\begin{tabular}{|c|c|c|c|c|}
\hline No & $\begin{array}{c}\text { Rentanga } \\
\text { n Skor }\end{array}$ & Frekuensi & $\begin{array}{c}\text { Persentase } \\
(\%)\end{array}$ & Kategori \\
\hline 1 & $85-100$ & 9 & $28,12 \%$ & $\begin{array}{l}\text { Sangat } \\
\text { Tinggi }\end{array}$ \\
\hline 2 & $65-84$ & 20 & $62,5 \%$ & Tinggi \\
\hline 3 & $55-64$ & 3 & $9,38 \%$ & Sedang \\
\hline 4 & $35-54$ & - & 0 & Rendah \\
\hline 5 & $0-34$ & - & 0 & $\begin{array}{l}\text { Sangat } \\
\text { Rendah }\end{array}$ \\
\hline \multicolumn{2}{|r|}{ Jumlah } & 32 & $100 \%$ & \\
\hline
\end{tabular}

Berdasarkan data pada tabel 15 sebanyak 9 siswa $(28,12 \%)$ memperoleh nilai pada kategori sangat tinggi. Selanjutnya, sebanyak 20 siswa $(62,5 \%)$ memperoleh nilai pada kategori tinggi dan sebanyak 3 siswa $(9,38 \%)$ memperoleh nilai pada kategori sedang. 


Kredo 4 (2021)
KREDO: Jurnal Ilmiah Bahasa dan Sastra
Terakreditasi Sinta 4 berdasarkan Keputusan
Direktorat Jenderal Penguatan Riset dan
Pengembangan, Kementerian Riset, Teknologi dan
Pendidikan Tinggi Republik Indonesia
Nomor: 23/E/KPT/2019.08 Agustus 2019
https://jurnal.umk.ac.id/index.php/kredo/index

\section{A. PEMBAHASAN}

Berdasarkan hasil penelitian menggunakan teknik sinektik maka dapat dikemukakan:

\section{Hasil Observasi}

Proses pembelajaran berlangsung mulai siklus I hingga siklus II terdapat sejumlah perubahan yang terjadi pada siswa. Perubahan-perubahan dasar ditemukan pada siswa adalah sebagai berikut:

Perhatian siswa pada proses pembelajaran dibandingkan siklus sebelumnya semakin baik. Hal ini ditandai dengan semakin banyaknya jumlah siswa yang mengikuti proses pembelajaran pada mata pelajaran Bahasa Indonesia. Jika pada siklus I ratarata persentase jumlah kehadiran siswa adalah sebanyak 94,78\%, maka pada siklus II mengalami peningkatan menjadi $100 \%$. Jumlah siswa yang mengajukan pertanyaan tentang materi yang belum dimengerti mengalami peningkatan. Pada siklus I hanya 39,56\% meningkat menjadi $51,04 \%$. Siswa yang memperhatikan pembahasan materi pembelajaran mengalami peningkatan siklus I sebanyak $87,9 \%$ sedangkan siklus II menjadi $89,6 \%$.

Jumlah siswa yang melaksanakan kegiatan lain saat proses pembelajaran pada siklus I $12,1 \%$ mengalami penurunan menjadi $10,4 \%$. Hal ini menunjukkan bahwa keaktifan siswa dalam proses pembelajaran semakin 381 | Jurnal Kredo

Vol. 4 No. 22021 meningkat. Jumlah siswa yang masih perlu bimbingan dalam proses pembelajaran pada siklus I 40,66\% sedangkan siklus II hanya 19,79\%. Hal ini menujukkan bahwa kemampuan siswa dalam memahami materi yang diajarkan semakin meningkat. Kemampuan dan keberanian siswa untuk aktif berdiskusi didalam kelas meningkat. Hal ini ditandai dengan banyaknya siswa yang mengacungkan tangan untuk berbicara di depan kelas. Pada siklus I sebanyak $61,54 \%$ sedangkan siklus II mengalami peningkatan menjadi $72,91 \%$.

Berdasarkan hasil pengamatan selama proses pembelajaran berlangsung, menunjukkan penelitian yang menggunakan teknik sinektik ini pada siklus I belum berhasil. Namun, pada siklus II aktivitas siswa mengalami perubahan yang positif. Secara umum, dibandingkan siklus II lebih banyak siswa yang aktif daripada siklus I.

\section{Hasil Evaluasi}

Secara umum frekuensi hasil evaluasi siswa dalam berdiskusi melalui teknik sinektik mengalami peningkatan pada siklus II. Pada siklus I nilai ratarata yang diperoleh siswa yaitu 37,5\% dengan kategori tuntas sedangkan pada siklus II nilai rata-rata yang diperoleh 90,6\% dengan kategori tuntas dan sudah menunjukkan Kriteria Ketuntasan Minimal (KKM). Hal ini menujukkan 


Kredo 4 (2021)
KREDO: Jurnal Ilmiah Bahasa dan Sastra
Terakreditasi Sinta 4 berdasarkan Keputusan
Direktorat Jenderal Penguatan Riset dan
Pengembangan, Kementerian Riset, Teknologi dan
Pendidikan Tinggi Republik Indonesia
Nomor: 23/E/KPT/2019.08 Agustus 2019
https://jurnal.umk.ac.id/index.php/kredo/index

adanya peningkatan hasil belajar pada kemampuan berdiskusi sebanyak $28,1 \%$.

\section{SIMPULAN DAN SARAN}

\section{A. Simpulan}

Berdasarkan hasil penelitian dan pembahasan menujukkan bahwa melalui pembelajaran teknik sinektik dapat meningkatkan kemampuan berdiskusi siswa kelas XI SMA Muhammadiyah 1 Unismuh Makassar. Untuk lebih jelasnya diuraikan sebagai berikut:

Kehadiran dan keaktifan siswa selama proses pembelajaran dari siklus I hingga siklus II mengalami peningkatan. Secara umum frekuensi hasil evaluasi siswa dalam berdiskusi melalui teknik sinektik mengalami peningkatan pada siklus II. Pada siklus I nilai rata-rata yang diperoleh siswa yaitu $37,5 \%$ dengan kategori tuntas sedangkan pada siklus II nilai rata-rata yang diperoleh siswa $90.6 \%$ dengan kategori tuntas dan sudah menujukkan adanya peningkatan hasil belajar pada kemampuan berdiskusi sebanyak $28,1 \%$.

\section{B. Saran}

Setelah melihat hasil penelitian yang telah dilaksanakan, maka penulis menyarankan:
1. Agar strategi pembelajaran dengan teknik sinektik diterapkan di dalam KBM didesain prosedurnya sedemikian rupa sehingga menjadi model pembelajaran yang lebih efektif terhadap pokok-pokok bahasan tertentu.

2. Diupayakan sedini mungkin untuk mengatasi kesulitan-kesulitan yang dialami, baik oleh siwa maupun guru dalam proses pembelajaran Hal ini dapat didasarkan dari refleksi berupa perubahan yang terjadi ketika proses pembelajaran berlangsung ataupunn diambil dari tanggapan siswa itu sendiri.

3. Agar pihak berwenang lebih memperhatikan mutu pendidikan dengan lebih memberikan dukungan moril dan maternal dalam setiap mengembangkan model pembelajaran yang dianggap cocok untuk

diterapkan

\section{DAFTAR PUSTAKA}

Aprinawati, Iis. 2017. Pengaruh Model Pembelajaran Sinektik Terhadap Kemampuan Menulis Puisi Bebas Siswa Sekolah Dasar Negeri 55 Pekanbaru. Jurnal Basicedu 1(1):31-44. 


Kredo 4 (2021)
KREDO: Jurnal Ilmiah Bahasa dan Sastra
Terakreditasi Sinta 4 berdasarkan Keputusan
Direktorat Jenderal Penguatan Riset dan
Pengembangan, Kementerian Riset, Teknologi dan
Pendidikan Tinggi Republik Indonesia
Nomor: 23/E/KPT/2019.08 Agustus 2019
https://jurnal.umk.ac.id/index.php/kredo/index

Cahyaningrum, Fitria, Andayani Andayani, and Budhi Setiawan. 2018. Kesantunan Berbahasa Siswa dalam Berdiskusi. Madah 9(1): 45-54.

Haling, Abdul. 2007. Belajar dan Pembelajaran. Makassar: Badan Penerbit UNM.

Indrizal, Edi. 2014. Diskusi Kelompok Terarah. Jurnal Antropologi: Isu-Isu Sosial Budaya 16(1): 75-82.

Karwati, Uus. 2012. Aplikasi Model Pembelajaran Sinektik (Synectic Model). Jurnal Seni \& Budaya Panggung Vol 22(2): 147-59.

Maulidiyah, Salis. 2017. Penerapan Model Sinektik Guna Meningkatkan Kemampuan Berpikir Divergen dan Hasil Belajar Peserta Didik dalam Mata Pelajaran Sejarah Kelas X MIPA 1 SMA Negeri 1 Jember.

Mutmainnah, Umi, and Aquami Aquami. 2016. Penerapan Model Sinektik (Synectics) Terhadap Kreativitas Belajar Siswa pada Mata Pelajaran Ilmu Pengetahuan Alam Kelas V di Madrasah Ibtidaiyah Hijriyah II Palembang. JIP (Jurnal Ilmiah PGMI) 2(1): 69-82.

Nugraha, Eggie. 2017. Model Sinektik Berorientasi Berpikir Kreatif dalam Pembelajaran Menulis Naskah Drama (Kuasi Eksperimen Terhadap Siswa Kelas VIII SMP PGII 2 Bandung). Literasi: Jurnal Ilmiah Pendidikan Bahasa, Sastra Indonesia dan Daerah 7(2): 121-31.

Rahayu, Sri Mugi. 2009. Eksperimen Model Investigasi Kelompok dan Model Sinektik dalam Pembelajaran Berdiskusi Siswa Kelas XI Jurusan Audio Video 1 dan Audio Video 2 SMKN 3 Semarang.

Reza, Muhammad, Yusak Hudiyono, and Masrur Yahya. 2020. Pengembangan Bahan Ajar Menulis Fabel dengan Model Sinektik pada Peserta Didik Kelas VII SMP Muhammadiyah 1 Balikpapan. Diglosia: Jurnal Kajian Bahasa, Sastra, dan Pengajarannya $3(2)$ : 179-88. 


Kredo 4 (2021)
KREDO: Jurnal Ilmiah Bahasa dan Sastra
Terakreditasi Sinta 4 berdasarkan Keputusan
Direktorat Jenderal Penguatan Riset dan
Pengembangan, Kementerian Riset, Teknologi dan
Pendidikan Tinggi Republik Indonesia
Nomor: 23/E/KPT/2019.08 Agustus 2019
https://jurnal.umk.ac.id/index.php/kredo/index

Suhartinah, Suhartinah. 2018. Peran Bimbingan Dengan Metode Diskusi Dalam Meningkatkan Interaksi Sosial Anak Yatim: Studi Fenomenologi Di Pondok Pesantren Yatim Dan Dhuafa Al-Kasyaf Kota Bandung.

Usman, Muthmainnah. 2019. 'Peningkatan Kemampuan Menyimak Berita Menggunakan Media Audiovisual dengan Metode Tanya Jawab Siswa Kelas VIIID SMP Negeri 5 Pallangga Kabupaten Gowa.

Utami, Nadya Hassela Ayunita. 2019. Pengaruh Penggunaan Metode Sinektika dalam Kompetensi Menulis Cerpen pada Siswa Kelas XI SMK Negeri 1 Palembang.

Wicaksono, Andri, and Ahmad Subhan Roza. 2015. Teori Pembelajaran Bahasa: Suatu Catatan Singkat. Garudhawaca.

Widodo, Ari. 2005. Taksonomi Tujuan Pembelajaran. Didaktis 4(2): 61-69.

Zubaidah, Siti. 2016. Keterampilan Abad Ke-21: Keterampilan Yang Diajarkan Melalui Pembelajaran. In Seminar Nasional Pendidikan, 1-17. 